Available online at : http://journal.unj.ac.id/unj/index.php/gjik

Gladi : Jurnal Ilmu Keolahragaan 12 (04) 2021, 314-325

Permalink/DOI: https://doi.org/10.21009/GJIK.124.010

\title{
DRIBBLING FUTSAL TRAINING MODEL BASED ON GAME FOR SENIOR HIGH SCHOOL
}

\author{
Achmad Alfi Suryanata ${ }^{1}$, Ramdan Pelana $^{1}$, Yasep Setiakarnawijaya ${ }^{1}$ \\ ${ }^{1}$ Pendidikan Jasmani, Pascasarjana Universitas Negeri Jakarta, \\ Komplek Universitas Negeri Jakarta Gedung M. Hatta Jl. Rawamangun Muka, Jakarta Timur, \\ Indonesia 13220
}

Corresponding author. Email: achmadalfis@gmail.com

\begin{abstract}
The goal to be achieved from this research and development is to produce a model of gameplay futsal dribbling skill-based skill training for senior high school. This research and development are conducted to get information about the development and implementation of the model of gamebased futsal dribbling skill training for senior high school and to know the effectiveness of the resulting model. This research uses Research \& Development ( R \& D) method from ADDIE. Subjects in this study were senior high school students who followed extracurricular futsal consisting of 60 children. The steps in this study are: analysis of the product to be created, designing the initial product description, developing a product framework that has been designed, implementing products that have been made with expert validation tests and testing them in large groups, and finally evaluating and testing the effectiveness of the product. The model effectiveness test uses the futsal dribbling skill test which is used to know the level of dribbling ability of the child before and after the treatment of the dribbling skill training model developed. Preliminary tests performed obtained level of dribbling ability of students is 11.3. After given treatment dribbling exercise model obtained the level of dribbling ability of students 10.1. On the significant test the difference with spss 20 obtained mean $=1.16217$ shows the difference of pre-test results and post-test results, $\mathrm{t}$-count $=18.666 \mathrm{df}=59$ and $\mathrm{p}$-value $=0.00<0.05$ which means there is a significant difference between before and after being given a modeling practice of skill futsal dribbling. This model of game-based futsal dribbling skills training for senior high school is effective for improving futsal dribbling skills for senior high school.
\end{abstract}

Keywords: model; exercise; futsal; dribbling

\section{INTRODUCTION}

Sports have increased a lot, especially in sports games. The public's interest is so great for sports games. Starting from the rules of the sport of the game itself to the emergence of a new sport that attracts a lot of people's attention to try it, namely futsal (Hawindri, 2016). 
Gladi Jurnal Ilmu Keolahragaan, 12 (04), September- 315

Achmad Alfi Suryanata, Ramdan Pelana, Yasep Setiakarnawijaya

Futsal is a sports game, this sport is in great demand by various groups of people, men or women. This is evident from the number of futsal field rental places, the establishment of futsal teams in various regions, as well as the holding of futsal extracurricular activities at schools both at the Junior High School, Senior High School and students (Santoso, 2020). Futsal continues to develop as a sports game. This growth has led to increasing demand for information related to futsal, to enable people to better understand the sport and its quality and complexity. In particular, there is a desire on the part of coaches, players, scientists and sports administrators to increase the depth of their knowledge, to help them contribute to the development of sport in their respective countries (Moore et al., 2014).

The futsal game focuses on ball control skills and techniques, to play futsal so well, a player is required to master some basic technical skills so well (Setia et al., 2020).

In the game of futsal, there are 5 (five) basic techniques, the basic technique of passing (passing), the basic technique of hold the ball (control), the basic technique of feed the stomach (chipping), the basic technique of dribbling (dribbling), the basic technique of shooting the ball (shooting) (Lhaksana, 2011). The five basic futsal techniques must be mastered by every futsal player. Each technique taught must be followed by a continuous training program so that the technique can be mastered by every player and turned into a skill. The skill in question is the ability to use game techniques that can be used in every condition or situation when competing on the field (Adi, 2019). the ability to perform skill movements of a sport and from the simplest skill movements to the most difficult skill movements, including deception which is the sport (Sutrisna et al., 2018).

One of the basic techniques that must be mastered by futsal players is the basic dribbling technique. In a futsal player, dribbling technique ability is very vital. Especially the dribbling ability of a player, because futsal is a team game and a player must depend on each other's team members to create a beautiful game and make the right decisions. So to perform well in the game, a player must be able to dribble well (Siswadi, 2018).

One of the tournaments was held in Jakarta (inter-school tournament). Several school representatives often experience defeat, one of which is a school representative from West Jakarta. The representative team from this school was only able to qualify in the group phase. After I observed, indeed many players from this team have not been 
able to overcome the problem when in a match situation there is a deadlock caused by the opponent's defense being very tight and difficult to penetrate, at that time the players who should be able to penetrate the opponent's defense quickly using confusion dribbling techniques to make decisions such as doing dribbling techniques that are not according to timing and making hasty decisions.

Futsal players who have good dribbling skills will try to pass the opponent if the ball cannot be passed to a friend because of the tight defense (Saputra \& Perdima, 2020). Therefore, the researchers observed the team's coach. The result was that the coach still needed a reference to a more varied dribbling training model. Because the players feel bored and do not develop so that it affects their appearance during the game.

Based on the above background, the author is interested in making a game-based futsal dribbling skill training model for Senior high school (high school). So that in a game situation all players can perform their dribbling skills effectively, efficiently, and fun.

\section{Model Development Concept}

Mulyatiningsih (2012) states that research is a way to find answers to questions or problem formulations using systematic and scientific procedures. Each type of research has a specific way of carrying it out, so someone who will conduct research needs to understand what type of research will be used.

According to Sukmadinata (in Hafizh, 2017) "research and development or Research and Development (R\&D) is a process or steps to develop a new product or improve an existing product, which can be accounted for" (Arus et al., 2019 So the research and development carried out must go through processes or steps so that new products or improvements to existing products can be accounted for their results and benefits.

This type of research is development research or better known as research and development is a process used to develop and validate some research product designs, as well as model validation and evaluation by some experts (expert judgment) in the field of education. (Irfandi \& Rahmat, 2013).

Thus, development research can be concluded as research that produces a product that has been analyzed in advance for its effectiveness in training or training, starting with needs analysis, product development and product testing. The product is evaluated and revised from the test results.

In this case, what researchers will develop is the development of a game-based futsal 
dribbling skill training model for Senior high school.

\section{Developed Concept Model}

The product manufacturing model in this development research is the ADDIE model. The selection of this model is based on the consideration that this model is programmed with systematic sequences of activities to solve learning problems related to learning resources that are by the needs and characteristics of the learner (Rohayati, 2018). Furthermore, researchers will conduct testing with the aim that the resulting product can be used and appropriate or effective. So that researcher conducting Research and Development research hope to excel in products produced from previous products.

The ADDIE model that will be developed by researchers in research and development is a game-based futsal dribbling skill training model for Senior high school.

\section{Exercise}

Exercise is a process that is carried out systematically and repeatedly over a relatively long period, with an increasing training load, so that there is an increase in overall motion stimulation of the body. The main aspects contained in the training materials include physical condition, technique, tactics, and mentality. (Rahardian et al., 2019). This is in line with the opinion of Tangkudung (2012) that exercise is a systematic process of practicing which is done repeatedly with an increasing number of training loads and their intensity. Systematic means the exercise is done regularly, planned, according to a schedule, from simple to more complex, from easy to difficult, from light to heavy.

Hawley, Hargreaves, Joyner, and Zierath (2014) state that Exercise represents a major challenge to whole-body homeostasis provoking widespread perturbations in numerous cells, tissues, and organs that are caused by or are a response to the increased metabolic activity of contracting skeletal muscles. Exercise will make all organs, cells and tissues work more as a result of increased muscle activity.

\section{Movement Skills}

Mustafa and Sugiharto (2020) state that motor skills are a skillful movement, namely the degree of consistent success in achieving an effective and efficient goal as a result of the combination of the cooperation of the nervous and muscular systems. This is in line with the opinion of Sudharto, Saddle and Lubis (2020) that a person's success in achieving the expertise to perform movement skills is influenced by many factors. Supporting factors include strength, agility, muscle coordination, and others. 
Gladi Jurnal Ilmu Keolahragaan, 12 (04), September- 318

Achmad Alfi Suryanata, Ramdan Pelana, Yasep Setiakarnawijaya

Persada (2018) states that in a motor learning process, a child is expected to be able to master motor skills, namely the ability to perform movement tasks optimally according to their abilities. Motor skills in each person are different because of many influencing factors, namely interest or willingness, ability, age and experience. One of the differences of each individual in developing a movement skill lies in motor skills or basic movement abilities. Motor ability or motor ability is a supporting factor for the implementation of a further skill that distinguishes individual abilities, so motor ability itself can also be understood as a limiting factor in one's movement appearance.

\section{Futsal}

Lhaksana (2011) states that futsal (futbol sala in Spanish means indoor football) is a soccer game that is played indoors. Futsal games tend to be more dynamic because of their fast movements, so this game tends to produce more goals than soccer games (Irfani et al., 2013).

Futsal is a 'small scale' of the sport of football. But even so, futsal is a different sport when compared to football. These differences are not only seen in the size of the field and the number of players, but these two sports also have differences in-game rules, playing techniques, formations and strategies to the attributes used (Erwindo, 2013).

\section{Dribbling}

Dribbling is the ability to dribble from one place to another while retaining control of the ball which is useful for avoiding opponent obstacles and for regulating the tempo of the game. (Taufik \& Guntur, 2019). Dribbling is kicking intermittently or slowly, therefore the part of the foot used in dribbling is the same as the part of the foot used to kick the ball (Yundarwati, 2019).

Irawan (2009) states that the basic technique of dribbling is important and absolutely must be possessed by every player. Dribbling is an attempt to move the ball from one area to another or by twisting to avoid the opponent, we must try to keep it rolling close to us, away from the opponent's feet during the game. This is in line with the opinion of Yanuar and Susilo (2017) that dribbling is a method of moving the ball from one point to another on the field using the feet. Dribbling must be an important concern for all players because players will find situations where they have to decide to dribble so that the opponent does not easily grab the ball, because the risk is very large if you make a mistake which results in the opponent quickly grabbing the ball and making a counterattack.

\section{Game}


Games are one of the dominant forms of social activity in early childhood. So through games, it allows children to develop the competencies and skills they need in a fun way (Prasetya et al., 2018). Game activities that can develop the psychological aspects of adolescents can be used as learning tools as preparation for the adult world. Game is used as a broad term that covers a wide and possible range of activities and behaviors. (Toha, 2020)

Hasan, Winarno and Tomi (2015) state that the game is an activity that is limited by complete rules and within the game itself. The child places limitations on the world of play and turns to play into a show or contest. because in a game there are several benefits as stated by Hartati et al., (2012) which states that the benefits of the game are fun, new skills in fine and gross motor skills, socialization, knowing the rules, selfconfidence, helping the development of thinking, and good emotional development. good (Shahrial et al., 2020).

\section{Characteristics of high school children}

Psychologists view high school-age children as individuals who are at an unclear stage in a person's developmental process. This ambiguity is because they are in a transition period from the childhood/child period to the adult period. At that time, they go through a period called adolescence or puberty. In general, they do not want to be called children or children, but if they are called adults, they are not ready to bear the title of adults. There are universal changes in adolescence, namely: 1). heightened emotions, whose intensity depends on the level of physical and psychological changes, 2 ). changes in body, interests, and roles that social groups are expected to play, create new problems, 3). with changing interests and behavior patterns, values also change, and 4). Most teenagers are ambivalent about any changes. All of this, in the end, has an impact on the development of cognitive (intelligence), affective (feeling), and psychomotor (movement) aspects (Samiudin, 2017).

Jim Lavin (2008) states that "Every child is capable of being creative. However, when pupils are forced to suppress their creativity by participating in an activity they dislike or those that do not motivate them, then their response can lead to inappropriate behavior" (Setia et al., 2020)

Developmental tasks in adolescence according to (Wong, 2008) include the following (1) achieving new and more mature relationships with peers both male and female, (2) achieving male and female social roles, (3) accept his physical condition and 
use his body effectively, (4) expect and achieve socially responsible behavior, (5) achieve emotional independence from parents and other adults, (6) prepare for an economic career, (7) prepare for marriage and family, (8) obtain a set of values and ethical systems as a guide for behavior to develop ideology (Setyawan, 2020).

\section{METHOD}

Personal (2014) stated that the stages of the ADDIE model are related to each other. Therefore, the use of this model needs to be carried out gradually and thoroughly. The systematic and systemic implementation of the ADDIE model will ensure the creation of an effective and efficient training program.

1) Analysis is the first stage in applying the ADDIE model to design and develop a training program. At this stage, a training program designer or training designer needs to carry out a training needs assessment process known as Training Need Analysis or TNA.

2) Design is the second stage in applying the ADDIE model to design and develop a training program. The design stage is carried out by identifying the sub-capabilities that need to be possessed by participants to master the general competencies of the training program. These sub-capabilities are specific and are referred to as special competencies for the training program. Sub-capabilities or objectives of the training program.

3) Development is the third stage in implementing the ADDIE model to create an effective and efficient training program. At this stage, training materials or training materials are produced or adapted so that they can be used in conveying the content or material of the training program to participants.

4) Implementation is the fourth step in applying the ADDIE model to design and develop a training program. At this stage the training program is carried out according to the design that has been developed previously, the instructor conveys the contents or training materials to the participants based on the program design that has been made previously.

5) Evaluation is the fifth or final stage in applying the ADDIE model to design and develop an effective and efficient training program. Evaluation can be interpreted as a process carried out to determine the value, price, and benefits of an object (Stufflebeam, 2011). 


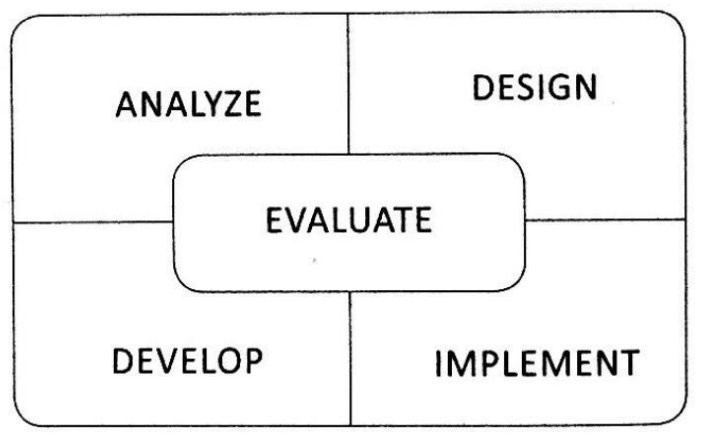

Figure 3.1 ADDIE MODEL

Source: (Benny A Personal, Design and Development of Competency-Based Training Program for ADDIE Implementation 2014, p.30)

In the picture above, the evaluation component is in the middle of the other components. This is because the evaluation component is a central component that can be used to assess the analysis, design, development, and implementation stages.

To facilitate the realization of an effective and efficient training program, systematic and systematic steps are needed. The instructional design and development model in this context needs to be applied. One simple design and development model that can be used to create an effective and efficient training program is the ADDIE model. This model contains the following five steps: analysis; design; development; and evaluation. At the analysis stage, performance problems need to be examined to find out the real problem and find the causal factors and solutions that can be used to overcome these problems.
The next stage needed to be able to create an effective and efficient training program is the design stage. This stage is done by making a design or design of learning programs that need to be realized to facilitate program participants in achieving the competencies that have been set. The design stage is carried out based on the results of the needs analysis that has been carried out in the previous stage. The design of a training program must refer to the competencies that must be possessed by training program participants after completing the program. The components of the learning system design that need to be considered in designing a training program are (a) a brief description of the training program: (b) the general competence of the training program; (c) the specific competence of the training program; (d) the content or materials of the training program; (e) a training strategy that includes methods, media, and sequences or sequences of learning activities that need to be carried out by participants; (f) evaluation of learning outcomes to determine the achievement of general competencies. The components of the learning system design above must be interrelated with each other so that they can be used in realizing an effective and efficient training program. 
Gladi Jurnal Ilmu Keolahragaan, 12 (04), September- 322

Achmad Alfi Suryanata, Ramdan Pelana, Yasep Setiakarnawijaya

The development stage is carried out to create training materials or training materials that can support the implementation of the training program. Training materials can be viewed as a medium that can be used as a means to facilitate the ongoing learning process of training program participants. Printed materials such as handouts, brochures, leaflets, and manuals can be used to deliver training content or programs. Real teaching materials and models can be used as training materials by the competencies that training program participants need to possess. Realia and models can be used as a means of simulation to practice specific skills.

The implementation phase is the realization of the previously designed and developed training program. At this stage the training program is drawn up, participants are invited, instructors are appointed, and a training venue is provided so that the training program can be carried out effectively and efficiently. Evaluation is the final step to create a valid training program, teaching the skills that training program participants need. The evaluation step is carried out to collect data and information needed to determine the effectiveness and efficiency of implementing a training program. In summary, the ADDIE model used in designing and developing a training program can be seen in the following illustration:

MODEL ADDIE

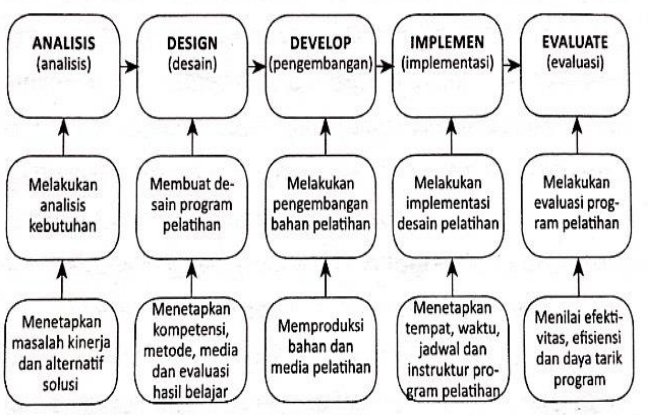

Figure 1. ADDIE MODEL

Source: (Benny A Personal, Design and Development of ADDIE Implementation Competency-Based Training Program 2014, p.176)

The approach used in this study is a qualitative and quantitative approach, which is an approach to finding answers to problems through the formulation of problems that have been formulated, namely in the implementation of extracurricular activities when dribbling training is given with a gamebased futsal dribbling skill training model for high school.

The final result of this development research is that this game-based futsal dribbling skill training model for Senior high school will produce a product in the form of a game-based futsal dribbling skill training model method complete with product specifications while at the same time testing 
the effectiveness of the futsal dribbling skill training model created, to increase motivation students in receiving futsal extracurricular material and training and can also be used as a coach's handle to improve futsal dribbling skills.

\section{RESULTS AND DISCUSSION}

In general, the results of this study are (1) a game-based futsal dribbling skill training model, (2) a game-based futsal dribbling skill training model manual. The game-based futsal dribbling skill training model was carried out at Lucky Futsal and BYWI Futsal, Joglo, West Jakarta using the Analysis, Design, Development, Implement, Evaluation (ADDIE) development method.

The development of this game-based futsal dribbling skill training model was carried out in 3 (three) high schools in West Jakarta, consisting of SMAN 57 Jakarta, SMAN 85 Jakarta, and SMAN 101 Jakarta.

This needs analysis is carried out, of course, by conducting observations and interviews with questions that aim to find out whether the development of a model is needed, analyze the conditions of previous exercises that have been carried out and the use of media or tools in the training process. Observations and interviews conducted of course on coaches and extracurricular Futsal students at Senior high school, observations and information obtained, researchers can conclude that coaches and students expect variations in training so that a game-based futsal dribbling skill training model is needed.

Based on the needs analysis, it can be seen that: (1) The coach needs innovations to train futsal dribbling skills (2) the coach needs a more varied, fun, and fun futsal dribbling skill training model that can activate the students in the futsal extracurricular training process (3) The coach agrees that if a gamebased futsal dribbling skill training model is developed for high school seniors (4) the coach needs media references in the form of electronic or non-electronic books to support the process of practicing futsal dribbling skills for high school seniors. The results and discussion contain the results of research findings and scientific discussions.

Test the effectiveness of the experimental group conducted on Futsal extracurricular students with 60 students as the subject with the application of a gamebased futsal dribbling skill training model for Senior high school that has been revised and is ready to be applied and implemented.

Based on the results of the output table above that the correlation coefficient of the game-based futsal dribbling skill training model for Senior high school before and after treatment is 0.962 with a P-value of $0.00<$ 
0.05 , there is a conclusion that the results of the correlation coefficient after and before treatment are significant.

The significant difference test with SPSS obtained t-count $=18.666 \mathrm{df}=59$ and p-value $==-0.00>0.05$, which means that there is a significant difference in the results of game-based futsal dribbling skills training for Senior high school.

Based on the information above, it can be said that the game-based futsal dribbling skill training model for senior high school that was developed can effectively improve dribbling skills in the futsal sport.

The following is a comparison of the averages of the game-based futsal dribbling skill training model for senior high school before giving treatment and after giving treatment with the game-based futsal dribbling skill training model for senior high school with a bar chart in the following figure:

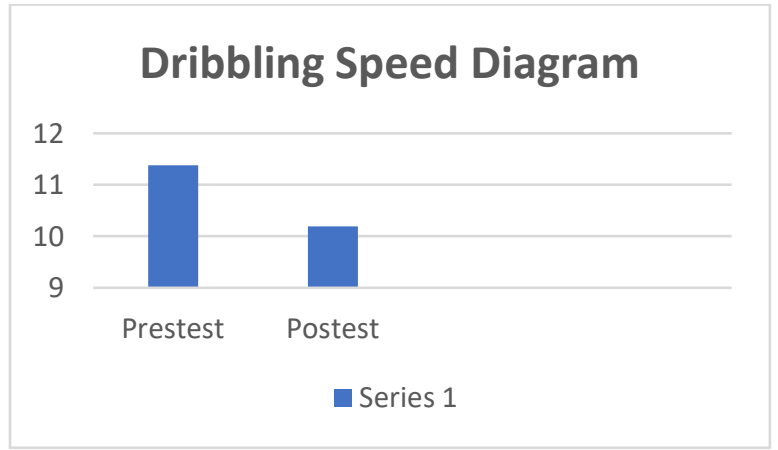

Figure 1. Dribbling Speed Diagram

The results of the experimental trial can be concluded that the game-based futsal dribbling skill training model for senior high school can be used to train dribbling skills effectively and is feasible to apply.

\section{CONCLUSION}

Based on the data obtained from the results of the study consisting of expert validation and effectiveness testing, it can be concluded that:

1. The game-based futsal dribbling skill training model that the researchers developed as many as 14 model items, this model can provide innovation to learn and carry out futsal dribbling skills training effectively, efficiently, and fun.

2. The material for the game-based futsal dribbling skill training model that researchers have developed, the results of the effectiveness test the average value of the game-based dribbling futsal skill training result (pretest) is 11.35 while the average value of the game-based futsal dribbling skill training result the final test (posttest) of 10.19 means that after the research, the significant difference test with SPSS 20 obtained the results of $\mathrm{t}$-count $=18.666 \mathrm{df}=59$ and $\mathrm{p}$-value $==-0.00>0.05$ which means there is a significant difference on the results of gamebased futsal dribbling skills training for senior high school . 
Gladi Jurnal Ilmu Keolahragaan, 12 (04), September- 325

Achmad Alfi Suryanata, Ramdan Pelana, Yasep Setiakarnawijaya

\section{REFERENCES}

Adi, S. H. D. (2019). Peningkaasastan Keterampilan Teknik Dasar Futsal Melalui Penggunaan Media Video pada Mahasiswa Putra Penghobi Futsal. Prosiding Seminar Nasional IPTEK Olahragasasasasasa (SENALOG), 2(1), $21-24$.

Arus, M. A., Simanjuntak, V., \& Supriatna, E. (2019). Pengembangan alat latihan tendangan (karate). 1-9.

Erwindo, A. (2013). Perancangan Buku Media Pendukung Pembelajaran Teknik Dasar Futsal Remaja Surabaya. Jurnal DKV Adiwarna, 1(2), 6.

Hasan, S., Winarno, M. E., \& Tomi, A. (2015). Pengembangan Model Permainan Gerak Dasar Lempar Untuk Siswa Kelas V Sdn Tawangargo 4 Karangploso Malang. Jurnal Pendidikan Olahraga, 4(2), 182-200.

Hawindri, B. S. (2016). Pemanfaatan Panduan Latihan Teknik Dasar Futsal Bagi Atlet Pemula. 284-292. https://doi.org/https://scholar.google.co. id/scholar?hl=id\&as_sdt=0\%2C5\&q=Pe manfaatan+Panduan+Latihan+Teknik+ Dasar+Futsal+Bagi+Atlet+Pemula\&btn $\mathrm{G}=$

Irawan, A. (2009). TEKNIK DASAR MODERN FUTSAL. Jakarta: PT. Pena
Pundi Aksara.

Irfandi, \& Rahmat, Z. (2013). PENGEMBANGAN MODEL LATIHAN KETERAMPILAN TEKNIK MENGGIRING SLALOM DAN MENGOPER DALAM SEPAKBOLA. Journal of Chemical Information and Modeling, 53(9), 16891699.

Irfani, M. H., Atiq, A., \& Yunitaningrum, W. (2013). Pengaruh Metode Bermain Terhadap Kemampuan Menggiring Bola Permainan Futsal Di Smkn 1 Rasau Jaya. Jurnal Pendidikan Dan Pembelajaran, 2(12).

Lhaksana, J. (2011). TAKTIK DAN STRATEGI FUTSAL MODERN. Jakarta: Be Champion

Moore, R., Bullough, S., Goldsmith, S., \& Edmondson, L. (2014). A Systematic Review of Futsal Literature. American Journal of Sports Science and Medicine, 2(3), $108-116$. https://doi.org/10.12691/ajssm-2-3-8

Mustafa, P. S., \& Sugiharto, S. (2020). Keterampilan Motorik Pada Pendidikan Jasmani Meningkatkan Pembelajaran Gerak Seumur Hidup. Sporta Saintika, $5(2)$,

199-218.

https://doi.org/10.24036/sporta.v5i2.133 Persada, B. G. (2018). Journal of Sport 
Gladi Jurnal Ilmu Keolahragaan, 12 (04), September- 326

Achmad Alfi Suryanata, Ramdan Pelana, Yasep Setiakarnawijaya

Coaching and Physical Education

Purwono Sidik Permono. 3(1), 42-45.

Prasetya, T. D., Wiradihardja, S., Suwarso, B.

K., \& Widiastuti, W. (2018). Model

Latihan Passing Bola Basket Berbasis

Permainan Anak Usia Pemula Tingkat

Smp. JUARA : Jurnal Olahraga, 3(2),

70.

https://doi.org/10.33222/juara.v3i2.237

Pribadi, A. B. (2014). Desain dan Pengembangan Program Pelatihan Berbabasis Kompetensi Impementasi Model ADDIE. Jakarta: PT. Prenada Media.

Rahardian, M., Hariyanto, E., \& Hariyoko. (2019). Pengaruh Model Latihan Ladder

Drill Lateral Dan Zig-Zag Hops Terhadap Peningkatan Kelincahan.

Indonesia Journal of Sports and

Physical Education, 1(1), 27-33.

Rohayati, Y. (2018). edukasi materi kesehatan NAPZA mata pelajaran Pendidikan Jasmani, Olahraga dan Kesehatan kelas X. Jenis penelitian ini adalah penelitian pengembangan. Prosedur pengembangan bahan ajar menggunakan model ADDIE meliputi lima tahap yaitu: tahap analisis (. 16(1), 33-43.

Samiudin. (2017). Pentingnya Memahami Perkembangan Anak Untuk
Menyesuaikan Cara Mengajar yang Diberikan. Pancawahana: Jurnal Studi Islam, 12(1), 1-9.

Santoso, W. A. (2020). Survei Daya Tahan Kardiovaskular dan Keterampilan Dasar Futsal Peserta Ekstrakurikuler. 2(10), 494-499.

Saputra, M., \& Perdima, F. E. (2020). KETERAMPILAN DRIBBLING PADA PERMAINAN FUTSAL DI AKADEMI DEHASEN KOTA BENGKULU. 1(1), 38-43.

Setia, C., Cahyadi, A., Nahdatul, U., Cirebon, U., Education, P., \& Lampung, U. (2020). Kinestetik: Jurnal Ilmiah Pendidikan Jasmani LEARNING MODEL OF DRIBBLING FUTSAL BALL GAME. 4(2).

Setyawan, H. (2020). PENGEMBANGAN MODEL OUTDOOR GAMES ACTIVITIES PADA PEMBELAJARAN PENDIDIKAN JASMANI OLAHRAGA DAN KESEHATAN SEKOLAH MENENGAH ATAS. 26(2), 45-55.

Siswadi, E. (2018). PENGARUH METODE LATIHAN TEKNIK DISTRIBUSI TERHADAP KETERAMPILAN DRIBBLING ZIG - ZAG PERMAINAN FUTSAL. 2(2), 173-178.

Sudharto, A., Pelana, R., \& Lubis, J. (2020). LATIHAN DRIBBLING

DALAM 
Gladi Jurnal Ilmu Keolahragaan, 12 (04), September- 327

Achmad Alfi Suryanata, Ramdan Pelana, Yasep Setiakarnawijaya

PERMAINAN SEPAKBOLA. 11(02), Yundarwati, S. (2019). MODEL $140-150$.

PEMBELAJARAN

MENGGIRING

Sutrisna, T., Asmawi, M., \& Pelana, R. SEPAKBOLA BERBASIS PERMAINAN SMP (2018). Model Latihan Keterampilan DI KOTA MATARAM TAHUN 2019. 61-68 Shooting Olahraga Petanque Untuk Pemula. Jurnal Segar, 7(1), 46-53. https://doi.org/10.21009/segar/0701.05

Syahrial, D., Sudijandoko, A., \& Priambodo, A. (2020). Pengaruh Permainan Kecil Berdasarkan Tingkat Motor Educability Terhadap Motivasi Dan Keterampilan Passing Permainan Futsal. 6(1), 195203.

Tangkudung, J. (2012). Kepelatihan Olahraga. Jakarta: Cerdas Jaya.

Taufik, M. S., \& Guntur, M. S. (2019). PENINGKATAN HASIL BELAJAR DRIBBLING SEPAKBOLA DENGAN PENGGUNAAN MEDIA AUDIO VISUAL yang mengembangkan aspek fisik, mental maupun emosional seseorang secara. 3, 43-54.

Toha, M. (2020). Analisis Keterampilan Dribbling Permainan Futsal Pada Remaja Putus Sekolah Di Desa Suka Maju Bengkulu Utara. Educative Sportive, $\quad$ 1(01), 6-12. https://doi.org/10.33258/edusport.v1i01. 1062 